\title{
MEDIEVAL ARISTOTELIANISM AND THE POETICS OF THE ENGLISH CORPUS CHRISTI DRAMA
}

\author{
Theodore K. Lerud
}

In an essay printed in the 1972 collection Medieval English Drama: Essays Critical and Contextual (Taylor and Nelson, eds.), Jerome Taylor argues for the dramatic unity of the Corpus Christi cycles by invoking the principles of Aristotle's Poetics:

This history presents a unified development from clearly defined beginning, through complication and crisis, to clearly defined end, so that the total dramatic projection of this history has a unity borrowed from the object it imitates. (Taylor 154)

While Taylor does not argue specifically for the influence of Aristotle on the Corpus Christi dramatists, the tell-tale phrases embedded in his essay ("object imitated," "classic stages of 'plot," "a serious action") nonetheless raise the interesting question of the possible influence of Aristotle on the dramatists, especially given what we know about the transmission of Aristotelian texts into the intellectual discourse of the West in the twelfth and early thirteenth centuries.

In opening for consideration the question of Aristotle's influence on medieval drama, we must address the issue on two levels. First, we must consider the probable or possible direct relationship between Aristotle's texts, including the logical texts of the Organon, the Physics, the Metaphysics, the Poetics, and De Anima, and the texts of the Corpus Christi dramatists. Second, and more important, in view of the way in which texts were copied and transmitted during the medieval period, we need to consider the transmission history of the texts and the likelihood, given that process, that they might have been encountered in an altered or synthesized form by a Corpus Christi dramatist. This issue can be studied by raw counting of available manuscripts, but perhaps more tellingly by noting the influence of key Aristotelian texts on authoritative texts more contemporary to the Corpus Christi dramatists. We can also invoke related texts which appear to 
corroborate or mirror concerns expressed in more clearly Aristotelian texts.

In general, such an investigation reveals that, while the Poetics appears to have available to medieval writers, it seems to have exercised little influence. While this fact is usually attributed to misreading and lack of interest, it might be more accurate to say that the medievals more correctly understood Aristotle as primarily a logician, and his Poetics as a relatively minor work, stemming from and subordinate to the principles set forth in the logical corpus. Even Averroes, whose "middle commentary," as translated by Hermannus in 1256, provided the Western medievals' main access to the Poetics, provided only one commentary on the Poetics, while he completed three each on the Posterior Analytics, the Physics, and the Metaphysics (Hardison 62). And Aquinas, the most well-known synthesizer and transmitter of Aristotle, never comments on it; yet he comments extensively on the Physics and Metaphysics (Pegis xlix). $\mathrm{He}$ also, in extensive commentaries and particularly in constructing his compelling model of human cognition in Part I, Questions 75-89, of the Summa Theologiae, seems singularly fascinated by the Aristotle of De Anima. Aristotle's emphases on the central role of sensibilia in human perception, and on the key position of the phantasms of the imagination in the operation of memory and understanding, become part of Aquinas' model. And in fact, it is this Aristotelian text, rather than the Poetics, that comes to provide a theoretical model for medieval drama.

But before turning to a more detailed consideration of the importance of De Anima, let us consider in a bit more detail the fate of the Poetics in the Middle Ages, addressing in particular two questions: 1) How was the Poetics understood in the Middle Ages? and 2) Why was it not a more compelling model for Aquinas and for the Corpus Christi and other dramatists?

From the point of view of mere availability, we can point to two translations of or commentaries on the Poetics which existed by the late thirteenth century. First, as noted above, Hermannus' Latin translation of Averroes' middle commentary on the Poetics was available from 1256. In fact, Hardison notes that no fewer than twenty-three manuscripts of the translation survive, and that the translation was printed in 1481 (64). So this commentary did exercise some influence; however, we must keep in mind its apparently idiosyncratic emphases as will be discussed below. In addition, William of Moerbeke, whom Aquinas probably knew 
during his time at Orvieto (1261-65) (Pegis xlviii), published a translation of the Poetics directly from the Greek in 1278. In fact, Pegis speculates that this meeting contributed to Aquinas' general interest in Aristotle as well as to William's interest in translating Aristotle from the Greek (xlviii). Yet the Poetics does not seem to have been anywhere near the center of that interest. Indeed, only two manuscripts of the translation survive, both from the thirteenth century, and it was not printed until 1953 (Hardison 64). Thus, the actual complete text of the Poetics, while it would have been available, though perhaps not easily accessible, to Aquinas and other medievals before its revitalization in cinquecento Italy, does not seem to have excited much interest.

Taking Hermannus' popular Latin version of Averroes' commentary as an indicator, the concepts of the Poetics, with its generic classifications and its discussion of tragedy as the imitation of an action, seem to have been equally foreign to the Arab Averroes and the German monk Hermannus. O. B. Hardison suggests that misreadings of two kinds run through the commentary and translation: 1) poetics is treated (like rhetoric) as a branch of logic; 2) poetry is understood as the art of praise and blame (63). In Averroes, poetry is analyzed in terms of its general device of comparison and its use of rhetorical tropes-simile, metaphor, analogy. In a typically medieval fashion, poetry is thus seen as the skillful use of figures. Further, poetry is understood as the art of praise and blame because it can thus be seen as a technique for moral instructions. Its object is understood to be the creation of virtuous and vicious characters who induce praise and blame from readers and thus provide models of proper and improper behavior. In this version, then, what poets do has little to do with the Aristotelian formulation of an imitation of an action; instead, they cleverly manipulate rhetorical figures to induce praise or blame and, accordingly, moral behavior.

In fact, by considering the emphases of Hermannus' translation along with another thirteenth-century essay on poetry, the Poetria Nova of Geoffrey of Vinsauf, we can illuminate thirteenth-century attitudes toward poetry and the Poetics and observe Hardison's "misreadings."

Taylor notwithstanding, what is notably lacking in the medieval treatments of poetics is any emphasis on the object of imitation-the substance and structure of the action that is the basis for a poem. Further, there seems to be little distinction between 


\section{Lerud}

genres. Geoffrey, who claims a knowledge of "artistic theory" as the basis of his judgments (21), spends most of his treatise (forty-five of seventy-eight pages, in the edition of the Pontifical Institute) on his section IV, which consists of exemplary "Ornaments of Style." This section consists of lists upon lists of tropes, beginning with metaphor, making for "difficult" and "easy" ornament. Other key sections deal with "Ordering the Material" and "Amplifications and Abbreviation"; the treatise also contains short sections on "Memory" and "Delivery." No clear generic distinctions are made, with examples and models being taken indiscriminately from classical story, political oratory, and biblical material. Under the section on ordering the material, the examples of beginnings seem to suggest an assumed moral purpose for poetry: e.g., one might begin with a proverb, "What is more desirable is more evanescent" (22), or an exemplum drawn from the end of the story: "Often the arrow learns to rebound on the archer; and the stroke, turned aside, to recoil on the striker" (23). In general, the emphasis is on ordering and "clothing" the matter (17), with no discussion of exactly what the appropriate matter, or "object," might be for a given effort or genre.

Clearly then, as revealed in the works of Averroes and Geoffrey of Vinsauf, the medieval conception of poetics, and of Aristotle's Poetics in particular, deviates significantly from our own. Indeed, Stephen Halliwell notes convincingly that the juxtaposition of poetics and rhetoric was not a purely medieval phenomenon, but may have stemmed from late Roman and Hellenistic attitudes. He points out that Aristotle's Poetics may not even have been widely known during the Alexandrine and Roman periods, and that Horace and Aristotle were seen by Hellenistic critics as similar in their concerns. Halliwell attributes this attitude to "the domination acquired over literary criticism during the Hellenistic period by rhetoric" (289). Like the medievals, Hellenistic critics were removed from the cultural context of the Poetics, with its admiration of Homeric epic and Athenian tragedy, and its sense of Platonic objections to poetry.

Thus, it seems unlikely that the Poetics-especially "our" modern Poetics-would have exercised any significant influence on the dramatists of Corpus Christi. However, it is nonetheless not accurate to say, as is often assumed, that, insofar as they had it available, the medievals warped or misunderstood the Poetics. Hardison, for example, speaks of "the process of assimilating Aristotle by misinterpretation that continued throughout the Middle 
Ages" (59). Halliwell, more recently, notes that "Hermannus' translation of Averroes, incorporating the misunderstandings that arose from study of an alien work at several removes from the original" (291), may have been regarded at Paris in the fourteenth century as a contribution to Aristotelian logic. The usual view is that with the printing of the Poetics at Venice in 1508 the true text was recovered from Byzantine libraries and more accurate readings, roughly similar to those of today, prevailed. The introduction to a more recent (1986) translation by Charles E. Butterworth of Averroes' commentary directly from the Arabic goes some way toward correcting the view that Averroes (and presumably Hermannus) misunderstood the Poetics.

According to Butterworth, whose English translation of Averroes' commentary on the Poetics is the first directly from the Arabic original, both Hermannus' Latin translation and Hardison's English translation of the Latin are inadequate in the rendering of Arabic poetry and inexact about Averroes' purpose (ix). After working closely with the Arabic text, Butterworth provides intriguing explanations of Hardison's two central points: 1) that Averroes saw the Poetics as related to rhetoric and, ultimately, as a branch of logic; 2) that Averroes, as one interested in reforming Arabic poetry, was interested in the Poetics as a didactic or moral text, and failed to see the contradiction between his own ethical and logical approaches.

On the first point, Butterworth notes interestingly that medieval commentators may not have been far wrong in placing the Poetics among Aristotle's logical works, since Aristotle himself may have regarded poetics as a part of logic. Like Halliwell, Butterworth sees Plato's dismissal of the poet, particularly in the passage in Book Ten of the Republic, as providing a context for AristotJe's Poetics. He goes on to state that Averroes' identification of poetry with the art of logic is "faithful to Aristotle's thought":

Much of what [Aristotle] has to say about diction and delivery, as well as about character and thought, is developed more fully in the Rhetoric. Moreover, at one point, he even suggests that poetry is a kind of rhetoric. Since the opening line of the Rhetoric defines that art as being the antistrophe or counterpart of dialectic, it is fair to infer that Aristotle considers poetry to be part of logic. (14) 
Butterworth further suggests that the "philosophic" perspective from which poetry is analyzed in the Poetics implies the superiority of philosophy to poetry.

Second, Butterworth concedes that Averrroes is clearly interested in the moral ends to which the Poetics may be put. Like Halliwell, he notes that Averroes' apparently skewed emphasis here may be owing at least in part to his lack of knowledge of epic and tragedy, there being nothing like these important Greek genres in Arabic culture. Averroes would have encountered nothing like the Iliad or Oedipus Rex; thus it is not surprising that he draws his examples from Arabic lyric poetry rather than from epic or tragedy, the genres so important to Aristotle's conception of poetics. Averroes apparently understands tragedy and comedy as "eulogy" and "satire," the distinction between the two having to do with whether the poem focuses on praise or blame. However, Butterworth attributes Averroes' attitude more to the rank and importance he ascribes to poetry than to any serious misunderstanding of Aristotle's definitions of comedy and tragedy. Averroes' sense of the uses of eulogy and satire, though perhaps not truly Aristotelian, is related to "the pedagogic or political role he [Averroes] assigns the poet" (13). For Aristotle, poetry is concerned with the actions of good and bad individuals because it "seeks to imitate human beings in action" (13) and therefore must enter the arena of character differentiation. In contrast, Averroes "portrays poets as seeking to encourage some actions and discourage others"; he even "qualifies the moral character of the poets according to whether they seek to imitate virtue or vice" (13).

In this context, it is also important to remember William of Moerbeke's accurate translation of the Poetics from the Greek, completed around 1278-a translation usually mentioned and dismissed by historians of the Poetics. In view of its existence, how can we explain that it is only preserved in two manuscripts, and apparently failed to derail the popularity of Hermannus' translation of Averroes' commentary? A possible answer, hinted at by Butterworth, is that possession of the complete translation did not contradict the medievals' prevailing sense of the Poetics as a part of logic, with connections to rhetoric, and that, in fact, the medievals were truer to Aristotle's own sense of his work than were later readers.

Indeed, the medieval view of Aristotle as, in the main, a logician seems accurate. Even in modern editions, it is clear that six 
of his works, more than for any other subject area, deal with topics in logic. And Aristotle himself, in stating the use of his Topics, his treatise on proper reasoning, in Book $I$, notes that the treatise is useful because "the possession of a plan of inquiry will enable us more easily to argue about the subject proposed.... It has a further use in relation to the principles used in the several sciences ... for dialectic is a process of criticism wherein lies the path to the principles of all inquiries" (Barnes 168; emphasis mine). ${ }^{1}$ If we master the methodology of the Topics, Aristotle continues, in a passage which suggests the relationship of logic to rhetoric, "we shall be in perfect possession of the way to proceed when we are in a position like that which we occupy in regard to rhetoric and medicine and faculties of that kind."

Similarly, in his Posterior Analytics Aristotle sets up the method of which rhetoric will be the counterpart and which will be followed in the inquiry into poetry. The assumption which opens the treatise is that "all teaching and all intellectual learning come about from already existing knowledge" (114). Aristotle says that this applies to both inductive and deductive reasoning, adding parenthetically that rhetorical arguments persuade in the same way that intellectual learning occurs, "for they do so either through examples, which is induction, or through enthymemes, which is induction" (114). Thus it becomes clear why Aristotle opens his Rhetoric with the statement that "Rhetoric is the counterpart of dialectic" (2152). Aristotle proceeds in the Posterior Analytics to discuss the way in which understanding must occur: it must "depend on things which are true and primitive and immediate and more familiar than and prior to and explanatory of the conclusion" (115); "Depending on things that are primitive is depending on appropriate principles; for I call the same thing primitive and a principlen (116).

By the time we get to the Poetics, we can note that it bears all the signs of being an exercise in logic on the subject of poetry. Poetry is no doubt an interesting subject to choose for analysis, in view of Platonic objections to the poet such as those advanced in Book Ten of the Republic. What needs to be kept clearly in mind (and what has been too frequently ignored by modern critics) is that the Poetics is neither a defense nor a condemnation of poetry, nor is it a prescriptive treatise on how to write poetry or tragedy; it is quite simply an analysis which follows the method as set forth in the logical works - an analysis which in fact could be carried out by any student of Aristotle with a grasp of his method and a fair 
acquaintance with contemporary poetry and tragedy. Thus, it opens by noting that it will consider both the genus and species of poetry, and suggests that the analysis will follow a particular "line of inquiry" (2316). Then, according to the procedure of the Posterior Analytics, the analysis commences: "Let us follow the natural order and begin with first principles" (2316). What impresses about the Poetics is not its inspiration but the sense of completeness in its methodology and distinctions.

In the twelfth century, John of Salisbury, in stating the prevailing medieval view of Aristotle as logician, only echoes Aristotle's own conception of the role of his logical treatises in his corpus. In Book III of his Metalogicon, he makes the case for Aristotle as logician, and for the study of his logical works as a necessary prologue to the study of his other works. According to John, the Categories is the essential work for the beginning student:

Taking a student as, so to speak, a helpless and speechless infant in regard to logic, [the Categories] instructs him in the ABCs of this science .... Aristotle prefaces his discussion by observations concerning equivocal, univocal, and derivative terms, for a knowledge of this distinction is essential for one who wishes to define, divide, and draw inferences. (Chap. 2, 150)

Arguing against those who say that the Categories, because it is elementary, is useless, John states that no one can become a logician without studying the book. He summarizes (156-57) the method explicated in the work, concluding that it

provides a most correct system of [scientific] research, and opens up a primary and evident highway for the perfection of knowledge. These seem to be the principal means of affording a complete knowledge of everything pertaining to the Peripatetic discipline, which is concerned with investigating the truth.

Following his discussion of the Categories with a discussion of Aristotle's On Interpretation, John suggests that Aristotle regarded these books as introductory to the body of logic-not "of the art" [de arte] but "for the art" [ad artem] (171). The actual body of the art, to be pursued next, consists of the remaining Aristotelian logical 
texts: the Topics, the Analytics, and the Refutations. Specifically, John notes that one who masters the body of the art of logic will be prepared for inquiry in all branches of learning:

If the last three are thoroughly mastered, and the habit of employing them is firmly fixed by practice and exercise, then one who applies them in demonstration, dialectic, or sophistry will have a wide command of invention and judgment in every branch of learning. (171)

Not only is John of Salisbury echoing the curricular structure under which he learned, but he expresses the prevailing view of Aristotle as primarily a logician. Thus it is not surprising that the Poetics and the Rhetoric would be seen as subordinate to the logical treatises.

Post-Renaissance conceptions of the Poetics have been dominated by two misperceptions, one now fairly well alleviated and the other not. First, particularly under the influence of neo-classical theorists, the Poetics came to be viewed as a prescriptive text on play writing. Samuel Johnson's critique of the idea of the three unities (actually not even in the Poetics) in his "Preface to Shakespeare" is an example of a reaction against such prescriptive notions, many of which are thought to be based on the Poetics. And certainly we can now congratulate ourselves on having moved beyond that erroneous view of the Poetics. However, a second misconception remains in the exaggerated sense we have of the importance of the Poetics in the overall corpus of Aristotle's work. It is as a result of this misconception that we accuse the medievals of misreading or distorting the Poetics; yet it is precisely here that the medieval view can serve as a corrective to our own. While it may be true that they showed more apparent interest in a fragmentary commentary on the Poetics than in an available accurate translation from the Greek, it appears that this may have been the result of conscious priorities on their part rather than on misreading. They understood the properly subordinate role of the Poetics in the larger corpus of Aristotle's works as an exercise in logic.

This attitude that poetic criticism is relatively unimportant correlates generally with the attitude reflected in some twelfthcentury writings on the structure of knowledge. Hugh of St. Victor's Didascalicon provides an interesting case study for our purposes because it places both poetry and "theatrics" in a larger structure of 


\section{Lenud}

human knowledge and learning. Theatrics is placed not under the theoretical (theology, mathematics, physics) or even the practical (ethical, economic, political) sciences, but among the mechanical sciences, alongside such arts as hunting and fabric making. Logic, the fourth and final part of philosophy (in addition to the three sciences listed above), includes grammar, which subsumes such things as "tropes, prose composition, verse composition, fables, and histories" (80) in Hugh's structure. In addition, Hugh warns that poetry belongs to the second sort of writing, appendages to the arts, which rarely treats of serious matters and is "only tangential to philosophy" (88).

Interestingly, when Hugh of St. Victor speaks of "theatrics" as one of the seven mechanical arts, he speaks of it in the past tense-i.e., "the theater, to which the people once used to gather for the performance" (79; emphasis mine). Contrary to some current views of the medieval sense of theater, Hugh seems to have a clear enough sense of the way in which classical drama was performed, distinguishing between recitals of epics and actual drama:

In the theater, epics were presented either by recitals or by acting out dramatic roles or using masks or puppets .... (79)

The significant thing here seems to be not a failed understanding of theater, but a sense of theater as something past. It does not appear (despite the footnote in Taylor's edition) that Hugh associates theater with the liturgical drama that was certainly flourishing by the $1120 \mathrm{~s}$. Theater is something past; the liturgical drama is something qualitatively other.

If the Poetics was read differently than it is now, and does not prove to be a central text in illuminating medieval drama, then where are we to look for a theory or "poetics" of medieval drama? Based on the notion, appearing in numerous fourteenth- and fifteenth-century texts, that drama is to be conceived as an image, I would argue that it is to the De Anima, rather than to the Poetics, that we might most fruitfully look for an understanding, indeed a "poetics" of medieval drama. For medieval drama, especially the Corpus Christi drama, was seen primarily not as theater or as poetry, but as a storehouse, or, in Aquinas' word, a thesaurus of images to move the mind of the auditor to spiritual understanding. The plays were, in the sense which Mary Carruthers has described 
in The Medieval Book of Memory, "copious" images, retained individually and collectively in the mind to be meditated upon and interpreted by the members of the community (see Carruthers 26-7, 181-83).

In the first place, it is clear that De Anima is a much more significant text in general for medieval commentators than the Poetics. Averroes comments on it in developing a formidable theory of intellect, and Emile Brehier lists its third book as one of the texts "in the foreground" in the Arab interpretation of Greek philosophy (Brehier 92, 100; Copleston 206-07). And Aquinas, who was very influential in creating the conception of the human soul that made the Corpus Christi plays possible, commented extensively on De Anima. Indeed, his conception of human cognition as set forth in Questions 75-89, Part 1, of the Summa is based heavily on the model of Aristotle's De Anima. Thus, Aristotle sets forth in De Anima the model which provides a basis for later understanding and defense of the efficacy of both images and drama.

Aristotle begins by distinguishing his view of the soul from those of his predecessors, which he initially identifies as collectively based too exclusively on two erroneous principles: movement and sensation (McKeon 160). He further sets himself apart from those who define the soul as composed of elements or of body in some form (175-76). His own definition, rather than viewing soul as some subtle form of matter, characterizes soul as "a substance in the sense of a form of a natural body having life potentially within it ${ }^{n}$ (182); the "essential whatness" of an organized body, possessed potentially of life (182). Soul is further identified with actuality-the "first grade of actuality" (182)—as against the potentially of matter.

Having defined the soul in this general way, Aristotle goes on to indentify and characterize its psychic powers, which he says are possessed variously by different living things. At this point in his explication (Book II, Chap. III), Aristotle identifies five psychic powers in the soul (and Aquinas follows him in this in S.T. 1: 78): the nutritive, appetitive, sensory, locomotive, and thinking powers (187). We learn that plants possess only the nutritive power, which is characterized by growth and decay, while it is the possession of the sensory power that distinguishes animals from plants. Further, that which possesses sensory powers also possesses appetite, for appetite is desire of that which is perceived as pleasant.

It is here, in the course of Aristotle's discussion of the 
nutritive power, that we encounter the teleological conception so important to the medieval synthesizers of Aristotle: reproduction is characterized as

the most natural act ... the production of another like itself, an animal producing an animal, a plant a plant, in order that, as far as its nature allows, it may partake in the eternal and divine. That is the goal toward which all things strive, that for the sake of which they do whatsoever their nature renders possible. (190)

Similarly, Aristotle states later, in discussing sensation, that "Nature does nothing in vain. For all things that exist by Nature are means to an end, or will be concomitants of means to an end" (242). This notion of an end or plan in nature is readily assimilated in the Providential design of Aquinas and other medieval commentators on Aristotle.

Aristotle next proceeds to discuss more extensively each of the psychic powers, though not in the precise order in which he has laid them out. He discusses the nutritive, sensory, and thinking powers in order, then proceeds to the powers of local movement and appetite. For our purposes, it is important to note that imagination (identified at one point in Book III [236] as one of the four parts of soul) plays a key, linking role in both these discussions.

Imagination first appears as a link between sensation and thinking. Aristotle devotes significant space in Book III, Chap. III, to its discussion, noting that "thinking is different from perceiving and is held to be in part imagination, in part judgement: we must therefore first mark off the sphere of imagination and then speak of judgement" (224). Although in forming opinions, we cannot escape the alternative of falsehood or truth, "imagining lies within our power whenever we wish." Thus, imagining is not the same as making a judgment-as Aristotle argues by evoking the use of mnemonics. Basic to our discussion here and to the defense of corporeal images later in the fourteenth and fifteenth centuries is Aristotle's assertion that "to the thinking soul images serve as if they were contents of perception. ... That is why the soul never thinks without an image" (233; emphasis mine).

Central to Aristotle's conception is the idea that the soul, both in perceiving (sensing) and in thinking, must be potentially identical in character to the object perceived or thought without 
being that object. Thus "all sense perception is a process of being potentially such as its object is actually" (213); similarly, in the sphere of thinking, "the thinking part of the soul must be, while impassible, capable of receiving the form of an object. . . Mind must be related to what is thinkable, as sense is to what is sensible" (227). Mind, in fact, can scarcely be said to exist apart from its activity of thinking:

[M] ind is in a sense whatever is thinkable, though actually it is nothing until it has thought. What it thinks must be in it just as characters may be said to be on a writing tablet on which as yet nothing actually stands written; this is exactly what happens in the mind. (229-30)

When the sensible objects are gone, imaginings continue to exist in the sense organs; images thus form the link that allows thinking and understanding to proceed:

[T] he faculty of thinking then thinks the forms in the images. . . [S]ometimes by means of the images or thoughts which are within the soul, just as if it were seeing, it calculates and deliberates what is to come by reference to what is present. (234)

Aristotle ends this section (Book III, Chap. 8) by reaffirming the importance of sense, and accordingly of images, to all understanding:

(2) when the mind is actively aware of anything it is necessarily aware of it along with an image .... (235)

Just as the imagination provides a key link in cognitive understanding, so is it a central cog in the movement of the will. In his discussion of local movement, Aristotle identifies appetite and mind as the sources of movement; however, appetite is the ultimate source, since "that which is the object of appetite is the stimulant of mind practical; and that which is last in the process of thinking is the beginning of the action" (238). Imagination, when it originates 
movement, also involves appetite. Furthering his discussion of the relationship of imagination to appetite and motion, Aristotle states that "inasmuch as an animal is capable of appetite it is capable of self-movement; it is not capable of appetite without possessing imagination" (240). Imagination may be distinguished as either calculative or sensitive, with calculative alone requiring synthetic ability-the ability "to make a unity out of several images" (241). Imagination is important, then, in providing that which moves the appetite.

Thus, in the spheres both of understanding and of will and desire, imagination has a key linking function. The key to the model lies in Aristotle's conclusion that "thinking, both speculative and practical, is regarded as akin to a form of perceiving" (McKeon 223). Thus Aristotle, like Albertus Magnus and Aquinas after him, roots thinking, even speculative understanding, firmly in the sensory realm of the soul. And the tie between sensing or perceiving and thinking is imagination-while different from either of these, it links them in an important way. For, as Aristotle notes, imagination, the basis of thought, "must be a movement resulting from an actual exercise of a power of sense" (227). At one point, in a passage which could suggest a concept of theater as memory image, he specifically associates imagination with mnemonics:

[I]magination lies within our power whenever we wish (e.g., we can call up a picture, as in the practice of mnemonics by the use of mental images). ..." (224)

These images then form the basis of judgment or understanding. And, as we have seen, in a statement of Aristotle's echoed by Aquinas, to the thinking soul, images serve as the contents of perception, such that "the soul never thinks without an image" (233). Through the synthesis of Aquinas and later medieval commentators, this role for images was transferred to the conception and defense of the images that were the Corpus Christi drama. Aquinas, drawing heavily on De Anima in the account of human cognition given in Part I, Questions 75-89 of the Summa Theologiae, sets up a context for a theory and defense of plays in the later Middle Ages. Aquinas' interest in De Anima is clear: it was among the works of Aristotle on which he wrote commentaries and it is also treated in his Disputed Questions (Pegis xlix-1). And he refers repeatedly to Aristotle, calling him simply "the Philosopher," 
in his section on the soul in the Summa: for example, Pegis records no fewer than fourteen direct references to De Anima in the four articles of Question 78 on the powers of the soul and twenty-nine in the thirteen articles of Question 79 on the soul's intellectual powers.

Like Aristotle, Aquinas views the imagination as an important link between the sensitive and the intellectual powers of the soul. Though the soul will have a new mode of understanding after its separation from the body, inasmuch as the soul is linked to the body, the image, or phantasm, is vital for understanding:

For the soul understands nothing without a phantasm, and there is no phantasm without the body, as the Philosopher says. (Pegis la: 75: 6; 691)

As noted above, in Question 78, Aquinas explicitly follows "the Philosopher" in designating the five powers of the soul as "the vegetative, the sensitive, the appetitive, the locomotive, and the intellectual" (1a: 78: 1; 734). Then in his explication of the sensitive powers in article 4 , he distinguishes between the five external senses and the five internal sense powers. Among the five internal powers are fantasy, imagination, and the memorative power. Thus, as with Aristotle and Albertus Magnus, imagination and memory are placed in the realm of the sensitive.

After discussing the external senses and establishing sight as the superior sense (a quality often cited by those defending medieval drama), Aquinas moves on to treat the interior sensitive powers. In a process of increasing abstraction, the common sense receives the forms derived from sensibilia, and these forms are retained or conserved by the fantasy or imagination:

[F]antasy or imagination is, as it were, a treasure-store [thesaurus] of forms received through the senses. (Blackfriars la: $78: 4 ; 138-9$ )

Such images are vital to understanding, since, at the next level of abstraction, in the realm of the intellectual powers, the agent intellect, through participation in the Divine intellect, "is able to illumine its own images [phantasmata illustrare]" (Blackfriars la: 79: $4 ; 160-1)$. Only through the presence of images can understanding occur. 


\section{Lerud}

As contemporary commentators, and no doubt the dramatists themselves, realized, the Corpus Christi plays can be seen as just such treasure-stores, or thesauri, of images vital to spiritual understanding. Both the Expositor or Doctor characters who frequently appear and the characters themselves, as they illumine their own significance, mirror the role of the agent intellect in moving spectators to abstract the significance of the dramatic images. The plays are defended by one contemporary as quick images:

[B]etere they ben holden in mennus minde and oftere rehersid by the pleyinge of hem than by the peintinge, for this is a deed bok, and tother a qu[i]ck. (Davidson, "Treatise" ll. 216-19)

The plays, as "rememoratijf signes," exist for the medieval audience as externalized quick images designed to move them toward spiritual understanding. Apparently, if we are to trust the account of Hugh of St. Victor, the liturgical drama, at least, was not even viewed as theater: rather, theater was a thing of the past. Thus, it is not surprising that the concepts of the Poetics were not current in the late Middle Ages; it is to Aristotle's De Anima and its transmission, rather than to his Poetics, that we must look for anything like a real "poetics" of medieval drama.

Elmhurst College 


\section{Lerud}

\section{Notes}

1. References to Aristotle's works are taken for the most part from the edition of Jonathan Barnes; however, the references to De Anima in the latter part of the paper are taken from Richard McKeon's fine translation.

2. For example, the Wycliffite author of the fifteenth-century "tretise of miraclis pleyinge" (ed. Davidson) speaks of plays as similar in kind to painted images (11. 211-219), and Reginald Pecock, contemporary Bishop of Chichester, speaks of a "quyk man ... sett in a play to be hangid nakid on a $\operatorname{cros}^{n}$ as an even truer "ymage" of Christ than a "stok or a stoon graued" (p. 221).

3. References to the Summa show Part, Question, and Article, with the page number(s) in the appropriate edition following the semicolon. Latin references to Aquinas, with their corresponding English translations, are taken from the Blackfriars edition (London 1970). 


\section{Lenud}

\section{Works Cited}

Aquinas, Thomas. Basic Writings. 2 Vols. Ed. Anton C. Pegis. New York: Random House, 1945.

. Summa Theologiae. 60 Vols. Gen. ed. Thomas Gilby, O.P. London: Blackfriars, 1964-80.

Aristotle. The Complete Works of Aristotle. Revised Oxford Translation. 2 Vols. Ed. Jonathan Barnes. Princeton: Princeton UP, 1984.

- Introduction to Aristotle. 2nd ed. Ed. Richard McKeon. Chicago: University of Chicago Press, 1973.

Brehier, Emile. The Middle Ages and the Renaissance. In The History of Philosophy. Trans. Wade Baskin. Chicago: University of Chicago Press, 1965.

Butterworth, Charles E., trans. and ed. Averroes' Middle Commentary on Aristotle's Poetics. Princeton: Princeton UP, 1986.

Carruthers, Mary J. The Book of Memory. Cambridge: Cambridge UP, 1990.

Copleston, Frederick, S.J. A History of Philosophy. Vol. II. Image Books. Garden City, NY: Doubleday, 1985.

Davidson, Clifford, ed. A Middle English Treatise on the Playing of Miracles. Washington, D.C.: University Press of America, 1981.

Geoffrey of Vinsauf. Poetria Nova. Trans. Margaret F. Nims. Toronto: Pontifical Institute, 1967.

Halliwell, Stephen. Aristotle's Poetics. Chapel Hill: University of North Carolina Press, 1986.

Hardison, O.B. "The Place of Averroes' Commentary on the Poetics in the History of Medieval Criticism." In Medieval and Renaissance Studies 4. Ed. John L. Lievsay. Durham, N.C.: 


\section{Lerud}

Duke UP, 1968.

Hugh of St. Victor. Didascalicon. Ed. and trans. Jerome Taylor. New York: Columbia UP, 1968.

John of Salisbury. Metalogicon. Ed. and trans. Daniel D. McGarry. Berkeley: University of California Press, 1955.

Pecock, Reginald. The Repressor of Over Much Blaming of the Clengy. Ed. Churchill Babington. London, 1860.

Taylor, Jerome. "The Dramatic Structure of the Middle English Corpus Christi, or Cycle, Plays." In Medieval English Drama: Essays Critical and Contextual. Eds. Jerome Taylor and Alan Nelson. Chicago: University of Chicago Press, 1972. 